\title{
Judicial Approaches to Political Questions: A CoMparative STUdy OF THE UNited STATES AND SOUTh Korea
}

\author{
Doori Song \\ Notre Dame Law School \\ dsong@nd.edu
}

SONG, Doori. Judicial Approaches to Political Questions: A Comparative Study of the United States and South Korea International and Comparative Law Review, 2019, vol. 19, no. 1, pp. 234-260. DOI: 10.2478/iclr-2019-0008

\begin{abstract}
Summary: The United States Supreme Court (USSC) and the Constitutional Court of Korea (CCK) have adopted sharply different positions regarding the justiciability of "political questions." On one hand, the USSC has generally refrained from adjudicating political questions, as shown in Nixon v. United States, Terlinden v. Ames, and Goldwater v. Carter. On the other hand, the CCK has regularly tried cases concerning political questions, as demonstrated in The Impeachment of the President (Roh Moo-hyun) Case and The Comfort Women Victims Case. The text of the U.S. and South Korean constitutions, their views about the proper role of the judiciary, and prudential factors explain why the USSC and the CCK have taken different approaches towards adjudicating political questions. Furthermore, the experiences of each country provide important lessons for the other: on one hand, the CCK experience has shown how a more active approach towards reviewing political questions can (1) create legal standards that keep government branches accountable in novel situations, (2) help prevent a political branch from acquiring tyrannical rule, and (3) enhance the judiciary's legitimacy in the public. On the other hand, the USSC experience has demonstrated how a more restrained approach towards reviewing political questions may (1) strengthen the commitment of all branches to the principle of separation of powers (2) enhance the consistency and predictability of judicial decisions, and (3) lead to resolutions of issues by the branch with the most training and expertise.
\end{abstract}

Keywords: Courts, Political Questions, Comparison, United States, South Korea

\section{Introduction}

As constitutional democracies, the United States and South Korea have similar commitments to popular sovereignty, representative government, and constitutional supremacy. ${ }^{1}$ Both countries also have independent judiciaries with powers of judicial review. ${ }^{2}$ But the United States Supreme Court (USSC) and

1 LIM, Jibong. A Comparative Study of the Constitutional Adjudication Systems of the U.S., Germany and Korea. Tulsa Journal of Comparative \& International Law, 1999, vol. 6, pp. $142-144$.

2 Id, pp. 152-153.

Published by Palacký University Olomouc, Czech Republic, 2019.

ISSN (print): 1213-8770; ISSN (online): 2464-6601 
the Constitutional Court of Korea (CCK) have adopted sharply different positions regarding the justiciability of "political questions." On one hand, the USSC has generally refused to hear cases concerning inherently political matters. ${ }^{3}$ The USSC has particularly committed itself to being apolitical and deferential to the principle of separation of powers. ${ }^{4}$ The CCK, by contrast, has regularly tried cases concerning political questions. ${ }^{5}$ For example, in the Impeachment of the President Case, the CCK intervened in and overruled the National Assembly's efforts to impeach then South Korean President Roh Moo-hyun. ${ }^{6}$ The CCK's willingness to intervene sharply contrasted with that of the USSC in Nixon v. United States, where the USSC decided not to challenge the Legislative Branch's impeachment proceedings. ${ }^{7}$ Furthermore, in The "Comfort Women" Victims Case, the CCK intervened in the Executive Branch's handling of foreign affairs by holding that the Executive's act of omission in a bilateral agreement was unconstitutional. ${ }^{8}$ The USSC, by contrast, has generally refrained from challenging the Executive's handling of treaties and foreign affairs. ${ }^{9}$

Why have the USSC and CCK used different approaches towards the justiciability of political questions? The answer to this question is important because the U.S. and South Korea share many similarities as constitutional democracies. ${ }^{10}$ The fact that the U.S. directly influenced the making of South Korea's constitution makes the presence of any disparity between the two even more intriguing. ${ }^{11}$

3 See Nixon v. United States, 506 U.S. 224, 237-38 (1993) (holding that the case presented a nonjusticiable political question); Baker v. Carr, 369 U.S. 186, 217 (1962) (providing the standard for determining whether a case presents nonjusticiable political question); see also MULHERN, Peter, J. In Defense of the Political Question Doctrine, University of Pennsylvania Law Review, 1988, vol. 137, p. 97.

4 Baker, 369 U.S. at 210 ("The nonjusticiability of a political question is primarily a function of the separation of powers.").

5 See, e.g., Constitutional Court of Korea [CCK] Aug. 30, 2011, 23-2(A) KCCR 366, 2006Hun-Ma788 (S. Kor.); Constitutional Court of Korea [CCK] May 14, 2004, 16-1 KCCR 609, 2004Hun-Na1 (S. Kor.); see also HAHM, Chaihark. Beyond "Law v. Politics" in Constitutional Adjudication: Lessons from South Korea. International Journal of Constitutional Law, 2012, vol. 10, p. 1.; PARK, Jonghyun. The Judicialization of Politics in Korea. Asian-Pacific Law \& Policy Journal, 2008, vol. 10, pp. 66-67.

6 Constitutional Court of Korea [CCK] May 14, 2004, 16-1 KCCR 609, 2004Hun-Na1 (S. Kor.).

7 See Nixon v. United States, 506 U.S. 224, 237-38 (1993). TOMOSZEK, Maxim. Impeachment in the U.S. Constitution and Practice - Implications for the Czech Constitution, International and Comparative Law Review, 2017, vol. 17, pp. 133-136.

8 Constitutional Court of Korea [CCK] Aug. 30, 2011, 23-2(A) KCCR 366, 2006Hun-Ma788 (S. Kor.).

9 See National City Bank v. Republic of China, 348 U.S. 356, 368 (1955); Sullivan v. Kidd, 254 U.S. 433, 442-43 (1921).

10 LIM, supra note 1, pp. 142-144.

11 See id. at 142-143; see also HAHM, Chaihark. To Make "We the People": Constitutional Founding in Postwar Japan and South Korea. International Journal of Constitutional Law, 2010, vol. 8, p. 3 . 
A comparative study of their judicial approaches is also important because it may provide more insight into the proper role of the judiciary in constitutional democracies. ${ }^{12}$ Furthermore, a comparative study of the USSC and CCK would help address the relative dearth of research concerning Asian legal systems in the English language. ${ }^{13}$ The findings of this study may contribute to the question of whether constitutionalism should be regarded as either a universal, purely Western, or some other kind of ideal. ${ }^{14}$

Furthermore, a goal of this Note is to compare the judicial approaches of the U.S. and South Korea while minimizing as much as possible the risks involved in comparative legal studies. One common risk is that comparative legal studies may "misinterpret[] foreign legal and constitutional materials by taking them out of context." 15 Skeptics of comparative studies regularly claim that proper consideration of contextual differences is difficult and often limited. ${ }^{16}$ Another common risk of comparative legal studies involves the privileging of one country's standards over those of the "other." Such privileging may cause comparativists to misinterpret apparent similarities, misunderstand the import of apparent differences, or impose specific biases onto the subjects. ${ }^{17}$ In order to minimize these risks, this Note attempts to compare, as neutrally as possible, the U.S. and South Korean approaches towards political questions while taking into account

12 There is robust debate over whether the judiciary should play a bigger role in politics. Compare COHEN, Harlan, Grant. A Politics-Reinforcing Political Question Doctrine. Arizona State Law Journal, 2017, vol. 49, pp. 5-6 (arguing that too much judicial restraint to hearing political questions is bad and that what is needed is a politics-reinforcing political question doctrine that can balance the need for robust review with the desire for robust debate.), and SKINNER, Gwynne. Misunderstood, Misconstrued, and Now Clearly Dead: The "Political Question Doctrine" as a Justiciability Doctrine. Journal of Law and Politics, 2014 , vol. 29, p. 431 (encouraging federal courts to not simply dismiss political question cases as nonjusticiable but to adjudicate more on the merits whether a branch acted constitutionally), with BARKOW, Rachel, E. More Supreme than Court? The Fall of the Political Question Doctrine and the Rise of Judicial Supremacy. Columbia Law Review, 2002, vol. 102, pp. 239-241 (contending that courts should be deferential to other branch's spheres of authority by adhering to the classical political question doctrine).

13 See LAU, Holning. Introduction to the Symposium Issue: Pluralism in Asia. North Carolina Journal of International Law \& Commercial Regulation, 2011. vol 36, p. 499 (noting that while there has been increased interest in Asian legal studies in recent decades, there is relatively little written about the topic in American legal journals).

14 See DORSEN, Norman et al., Comparative Constitutionalism: Cases and Materials. Third Edition. St. Paul: West Academic Publishing, 2016, pp. 38-39 (posing the question "Is constitutionalism a purely Western ideal?" and providing some insight into the matter); see also LAU, Holning. The Language of Westernization in Legal Commentary. American Journal of Comparative Law, 2013, vol. 61, p. 508 (reviewing the use of the term "western" in legal studies and proposing for the substitution of the language of "western" with alternative terminology).

15 DORSEN et al., supra note 14, p. 2.

16 Id. at 2-3.

17 Id. at 2 .

Published by Palacký University Olomouc, Czech Republic, 2019.

ISSN (print): 1213-8770; ISSN (online): 2464-6601 
how their legal norms and institutions are embedded in each of their respective contexts.

This Note proceeds in Part II with a general overview of the doctrinal relationship between courts and political questions in order to establish a framework by which the U.S. and South Korean judicial approaches can be compared. Part III reviews the judicial systems of the CCK and USSC and then compares several "political question" cases in the context of the U.S. and South Korea. Part IV proffers reasons why the USSC and CCK have different approaches towards the justiciability of political questions. The reasons focus primarily on constitutional text, constructional structure, methods of judicial review, and history. Finally, Part V concludes with an overview of the lessons that the USSC and CCK can learn from each other about how to better deal with political questions.

\section{The Political Question Doctrine}

The political question doctrine rests upon the principle that some constitutional issues are nonjusticiable because of their political nature and structural affiliation with another branch of government. ${ }^{18}$ Although the specific contours of the right are not entirely clear, it is generally established that the doctrine inhibits the adjudication of issues that belong more properly to the decision-making authority of the legislature or the executive. ${ }^{19}$ The doctrine does not block off political issues due to lack of jurisdiction. ${ }^{20}$ Neither does it avoid certain issues merely because they are politically charged. ${ }^{21}$ For example, courts have regularly adjudicated the issue of abortion despite its highly politicized character. ${ }^{22}$ Rather, the doctrine wards off issues that are political in the sense that they involve sensitive matters traditionally resolved by other branches of government. ${ }^{23}$

The question of whether the doctrine should be adopted has been a subject of much debate. On one hand, advocates of the political question doctrine have articulated three mains reasons for its adoption. First, constitutional text often advises the judiciary that certain issues should be resolved solely by other branches of government. ${ }^{24}$ For example, the text of a constitution might explic-

18 DORSEN et al., supra note 14, pp. 194-195.

19 CHEMERINSKY, Erwin, Constitutional Law: Principles and Policies. Fifth Edition. New York: Wolters Kluwer Law \& Business, 2015, p. 135.

20 Id.

21 DORSEN et al., supra note 14, p. 194.

22 Id.

23 CHEMERINSKY, supra note 19, p. 135.

24 See SCHAUER, Frederick. Easy Cases. Southern California Law Review, 1985, vol. 58, p. 404 ("The focus of constitutional litigation on certain substantive areas is importantly, although certainly not exclusively, a product of linguistic design, in which relatively precise language forestalls litigation with respect even to matters of great moment, while relatively vague language encourages litigation, even as to matters that are comparatively trivial."); see also Baker v. Carr, 369 U.S. 186, 217 (1962) ("[P]rominent on the surface of any case 
itly state that the executive branch has sole power to conduct foreign affairs. As such, the political question doctrine would advise the judiciary to avoid adjudicating issues concerning foreign policy matters, such as the enforcement of treaties or recognition of new states. The purpose of such restraint is to uphold the constitution's commitment to separation of powers and to promote mutual respect between the branches. ${ }^{25}$ Interpreting the constitution based on the plain language of the text is also a core function of the judiciary. ${ }^{26}$

Second, advocates of the doctrine claim that the judiciary often lacks the capacity to answer political questions. ${ }^{27}$ As a jurisprudential matter, courts may have no legal standard by which to review certain political questions. ${ }^{28}$ Without such standards, the judiciary would overstep the scope of its duty to apply, and not make, the law if it were to answer such questions. ${ }^{29}$ Furthermore, as a practical matter, courts may be less able to review certain cases where another branch of government has more experience and expertise. ${ }^{30}$ Compared to the legislature, for example, the judiciary might lack the aptitude needed to effectively review impeachment proceedings. ${ }^{31}$ Because other branches of government are often in a better position to monitor their own proceedings, advocates of the political question doctrine claim that the judiciary should be cautious about meddling into the affairs of other branches. ${ }^{32}$

Finally, advocates of the doctrine argue that, as a prudential matter, courts should avoid adjudicating political questions in order to protect the judiciary's legitimacy and prestige. ${ }^{33}$ Adjudicating cases for which courts have no applicable legal standard or expertise poses the risk of producing "bad" law and hurting the judiciary's reputation. ${ }^{34}$ By contrast, declining to review politically sensitive

held to involve a political question is found a textually demonstrable commitment of the issue to a coordinate political department...”).

25 DORSEN et al., supra note 14, p. 194.

26 SCHAUER, supra note 24, p. 404.

27 CHEMERINSKY, supra note 19, p. 138.

28 See HENKIN, Louis. Is There a "Political Question" Doctrine?. Yale Law Journal, 1976, vol. 85, p. 599; FIELD, Oliver, P. The Doctrine of Political Questions in the Federal Courts. Minnesota Law Review, 1924, vol. 8, p. 512.

29 DORSEN et al., supra note 14, pp. 247-250. DANSBY, Joshua W. Rule of Law in the United States. Stability is One of the World's Most Valued Commodities. International and Comparative Law Review, 2017, vol. 17, p. 147.

30 CHEMERINSKY, supra note 19, p. 138 (citing SCHARPF, Fritz. Judicial Review and the Political Question Doctrine: A Functional Analysis. Yale Law Journal, 1966, vol. 75, p. 517).

31 SCHARPF, Fritz. Judicial Review and the Political Question Doctrine: A Functional Analysis. Yale Law Journal, 1966, vol. 75, pp. 539-540.

32 CHEMERINSKY, supra note 19, p. 138.

33 BICKEL, Alexander, The Least Dangerous Branch. New Haven: Yale University Press, 1962, p. 184.

34 Id. at 169-170. SIMONIS, Mindaugas. The Role of Judicial Ethics in Court Administration: From Setting the Objectives to Practical Implementation. Baltic Journal of Law \& Politics, 
matters may promote comity between the government branches and strengthen the discretionary powers of the judiciary. ${ }^{35}$ Furthermore, the judiciary has often deferred to the policy choices and value judgments of the legislative and executive branches for reasons concerning democratic legitimacy. ${ }^{36}$ Because the legislature and the executive are often elected by the people, it may be undemocratic for unelected judges to repudiate the decisions of elected representatives. ${ }^{37}$

On the other hand, critics of the political question doctrine have offered three justifications of their own. First, constitutional text is often vague as to whether an issue is solely reserved to another branch of government. ${ }^{38}$ The text is often written in broad terms with no explicit guidance for how certain issues should be resolved. As such, critics of the political question doctrine claim that the judiciary should not divest itself of review powers when the constitution does not explicitly say to do so. ${ }^{39}$ Furthermore, there are fewer separation of powers concerns when the text is unclear as to whether a specific branch has sole authority over an issue..$^{40}$ Because the main responsibility of the judiciary is to protect and uphold the constitution, critics of the political question doctrine claim that courts should not hesitate to check constitutionally-suspect proceedings of other government branches. ${ }^{41}$

Second, critics of the doctrine claim that lack of judicial standards is no reason for courts to avoid political questions because developing new rules and standards is part of the judicial process. ${ }^{42}$ The judiciary's responsibility is not just to apply the law, but also to interpret and develop the law in ways that establish new standards over time. ${ }^{43}$ For example, many constitutions provide no guidance for how to interpret the terms "dignity," "privacy," or "person," but courts throughout the world have developed manageable standards for cases concerning human rights, abortion, and capital punishment. ${ }^{44}$ Thus, critics of the politi$\mathrm{cal}$ question doctrine claim that courts should not abstain from hearing political issues merely because there is little or no body of law to work with ${ }^{45}$ Even if another branch of government has more expertise in handling a politically sensi-

2017, vol. 10, pp. 92-93.

35 CHEMERINSKY, supra note 19, p. 138.

36 BICKEL, supra note 33, p. 184.

37 Id.

38 CHEMERINSKY, supra note 19, p. 137.

39 Id. at 139.

40 DORSEN et al., supra note 14, pp. 247-250.

41 REDISH, Martin. Judicial Review and the Political Question. Northwestern University Law Review, 1985, vol. 79, pp. 1045-1046; CHEMERINSKY, Erwin, Interpreting the Constitution. New York: Praeger Publishers, 1987, pp. 99-105.

42 REDISH, supra note 41, pp. 1046-1047.

43 Id.

44 DORSEN et al., supra note 14, pp. 725-736.

45 REDISH, supra note 41, pp. 1046-1047. 
tive matter, courts have a duty to interpret and develop the law to ensure that all government branches comply with the constitution. ${ }^{46}$

Finally, as a prudential matter, critics of the doctrine argue that adjudicating political questions would not hurt, but would rather enhance the judiciary's legitimacy and prestige. ${ }^{47}$ Given that the role of the judiciary is to say what the law is, the legitimacy of the court would decline if it refrained too often from reviewing the constitutionality of political issues. ${ }^{48}$ Critics of the doctrine also claim that courts need not worry about reviewing the decisions of elected legislative or executive officials because judicial decisions are not supposed to be based on what the masses want; ${ }^{49}$ rather, judicial decisions are supposed to be based on what the constitution says..$^{50}$ As the final interpreter of the constitution, the judiciary should be open to adjudicating politically sensitive questions.

Overall, advocates of the political question doctrine have argued that courts should refrain from adjudicating political issues because (1) constitutional text often reserves the issues to another government branch, (2) courts often lack manageable legal standards by which to review the issues, and (3) adjudicating political issues would hurt the legitimacy and prestige of the judiciary. Meanwhile, critics of the political question doctrine have argued that courts should be open to reviewing political issues because (1) the judiciary's role is to protect the constitution even if it requires checking other branches, (2) developing new legal standards is part of the judicial process, and (3) adjudicating political issues would enhance the legitimacy and prestige of the judiciary.

\section{Judicial Responses to Political Questions in the U.S. and South Korea}

\subsection{Judicial Systems of the U.S. and South Korea}

The Constitutional Court of Korea (CCK) was established on October 29, 1987 for the purpose of protecting the Constitution as the supreme law of the land.$^{51}$ Its primary function is to protect the people's basic rights from the abuse of public power and to ensure that public authorities operate within the boundaries of the Constitution. ${ }^{52}$ The CCK was established following decades of authoritarian government leadership. ${ }^{53}$ Although constitutional review commit-

46 Id. at 1045-1046; CHEMERINSKY, supra note 41, pp. 99-105.

47 CHEMERINSKY, supra note 41, pp. 133-138.

48 CHEMERINSKY, supra note 19, p. 139.

$49 \mathrm{Id}$.

50 Id.

51 Constitutional Court of Korea, About the Court. [online]. Available at: <http://english. ccourt.go.kr/cckhome/eng/introduction/aboutTheCourt/aboutTheCourt.do $>$ Accessed: 08.12.2018.

$52 \mathrm{Id}$.

53 Constitutional Court of Korea, History of Constitutional Adjudication. [online]. Available at: <http://english.ccourt.go.kr/cckhome/eng/introduction/history/historyOfConsAdju. 
tees existed ever since the founding of South Korea's Constitution in 1948, those committees were largely ineffective as they posed no challenge to authoritarian rulers. ${ }^{54}$ However, after years of public demonstrations for democracy and assurance of basic rights, the people prompted the ruling party and the opposition party to agree to set up the CCK in $1987 .{ }^{55}$ In a national referendum, $93.1 \%$ of voters in 1987 supported the establishment of the CCK. ${ }^{56}$ To this day, the CCK has consistently scored the highest among state organizations in the trustworthiness category. ${ }^{57}$ The CCK is viewed to derive its legitimacy from the will of the people. $^{58}$

The CCK is composed of nine Justices: three are appointed by the President who heads the Executive Branch; another three are elected by the National Assembly, the legislative organ that creates all the laws of the country; and the final three Justices are designated by the Chief Justice of the Supreme Court, the court of last resort for cases outside the CCK's jurisdiction..$^{59}$ Each Justice serves a term of six years and may be reappointed. ${ }^{60}$ One Justice is appointed President of the CCK by the South Korean President with the consent of the National Assembly. ${ }^{61}$

The CCK has jurisdiction over five types of cases. ${ }^{62}$ First, the CCK has power to review the constitutionality of statutes, including those passed by the National Assembly or by the President in the form of an executive order. ${ }^{63}$ The purpose of this power is to promote checks and balances between the branches. ${ }^{64}$ Second, the CCK has power to review constitutional complaints from any citizen whose basic rights were allegedly violated by a governmental power. ${ }^{65}$ The complain-

do> Accessed: 08.12.2018.

54 Id.

55 Id.

56 The Constitutional Court of Korea: The First Ten Years of the Korean Constitutional Court. Sixteenth Volume. Seoul, 2001

57 HAHM, supra note 5, p. 23 n.118 ("According to a survey conducted for five consecutive years on the influence and trustworthiness of major public and private organizations, the Constitutional Court of Korea has consistently scored the highest among state organiza58 Id. tions in the trustworthiness category.").

59 Constitution of the Republic of Korea Oct. 29, 1987, chap. VI, art. 111 (S. Kor.). Constitutional Court of Korea, Organization: Justices. [online]. Available at: <http://english.ccourt.go.kr/ cckhome/eng/introduction/organization/organization.do\#none> Accessed: 08.12.2018.

60 Constitution of the Republic of Korea Oct. 29, 1987, chap. V, art. 105 (S. Kor.).

61 Id. at chap. V, art. 104 (S. Kor.).

$62 I d$. at chap. VI, art. 111(1) (S. Kor.).

63 Constitutional Court of Korea, Jurisdiction: Adjudication on the Constitutionality of Statutes. [online]. Available at: <http://english.ccourt.go.kr/cckhome/eng/jurisdiction/jurisdiction/ adjuOnConsOfStatutes.do > Accessed: 08.12.2018.

64 Id.

65 Constitutional Court of Korea, Jurisdiction: Constitutional Complaint. [online]. Available at: <http://english.ccourt.go.kr/cckhome/eng/jurisdiction/jurisdiction/adjuOnConsOf- 
ant must first exhaust all alternative remedial mechanisms before filing with the CCK. ${ }^{66}$ Third, the CCK has power to review competence disputes between state and local governments and agencies about the duties and authorities of each institution. ${ }^{67}$ The purpose of this power is to ensure the orderly operation of government functions and to preserve separation of powers. ${ }^{68}$ The CCK's decision on competence disputes is binding on all state agencies and local governments. ${ }^{69}$ Fourth, the CCK has exclusive jurisdiction over impeachment proceedings brought against high-ranking public officials, such as the President, the Prime Minister, and the Ministers of Executive Ministries. ${ }^{70}$ The impeachment proceedings originate in the National Assembly when the public official is found to have violated the Constitution or other laws in the performance of official duties. ${ }^{71}$ The impeachment prosecutor then requests adjudication by presenting the case to the CCK. ${ }^{72}$ Finally, the CCK has power to review requests from the Executive to dissolve a political party. ${ }^{73}$ If a political party is found to have engaged in activities harmful to the basic order of democracy, then the CCK may order that the party be dissolved. ${ }^{74}$

The U.S. Constitution, on the other hand, was established in 1788 as the supreme law of the land. ${ }^{75}$ A primary purpose of the Constitution is to protect the individual liberties of the people. ${ }^{76}$ The Constitution divides government powers between the Executive, Legislative, and Judicial branches through a checks and balances system designed to prevent one branch from acquiring tyrannical rule. ${ }^{77}$ The judicial power of the federal government lies in the United States Supreme Court (USSC). ${ }^{78}$

Since 1869, the USSC has consisted of nine Justices, all of whom are appointed by the President of the Executive branch with the advice and consent of the

66 Id.

Statutes.do> Accessed: 08.12.2018.

67 Constitutional Court of Korea, Jurisdiction: Adjudication on Competence Dispute. [online]. Available at: <http://english.ccourt.go.kr/cckhome/eng/jurisdiction/jurisdiction/adjuOnConsOfStatutes.do $>$ Accessed: 08.12.2018.

68 Id.

69 Id.

70 Constitutional Court of Korea, Jurisdiction: Adjudication on Impeachment. [online]. Available at: <http://english.ccourt.go.kr/cckhome/eng/jurisdiction/jurisdiction/adjuOnConsOfStatutes.do> Accessed: 08.12.2018.

71 Id.

$72 \mathrm{Id}$.

73 Constitutional Court of Korea, Jurisdiction: Adjudication on Dissolution of a Political Party. [online]. Available at: <http://english.ccourt.go.kr/cckhome/eng/jurisdiction/jurisdiction/ adjuOnConsOfStatutes.do> Accessed: 08.12.2018.

$74 \mathrm{Id}$.

75 CHEMERINSKY, supra note 41, pp. 9-16.

76 Id. at 4-6.

77 Id. at $1-3$.

78 U.S. Const. art. III, $\$ 1$. 
Senate. ${ }^{79}$ USSC Justices have life tenure, but in theory can be impeached. ${ }^{80}$ The purpose of lifetime appointment is to help ensure that the decisions of the Justices are based on the merits of the case and not on political pressures or personal motives to get reelected. ${ }^{81}$

Article III of the Constitution defines the scope of the USSC's jurisdiction. ${ }^{82}$ The USSC has original jurisdiction over cases involving ambassadors and other public ministers, and suits between two or more states. ${ }^{83}$ In almost all other cases the USSC has appellate jurisdiction to review points of constitutional or federal law. ${ }^{84}$ The USSC derives much of its legitimacy from being the final interpreter of the Constitution, from protecting the constitutional rights of the people, and from its power to review the constitutionality of legislation and executive orders. $^{85}$

\subsection{Judicial Responses in the Context of Impeachment}

The USSC demonstrated its practice of generally not reviewing "political questions" in Nixon $v$. United States, ${ }^{86}$ where the issue before the USSC was whether the Senate's decision to impeach a high-ranking public official was unconstitutional. ${ }^{87}$ The public official in question was a federal district judge, Walter Nixon, who was convicted of making false statements to a grand jury. ${ }^{88}$ After Nixon refused to resign from his position, the House of Representatives adopted articles of impeachment, and the Senate appointed a committee to hold a hearing with Nixon. ${ }^{89}$ The committee ultimately recommended to the entire Senate that Nixon be removed from office..$^{90}$ The Senate voted to convict the judge by more than the constitutionally required two-thirds majority, and judgment was entered to remove Nixon from office. ${ }^{91}$ Nixon responded that his impeachment was void on the ground that the Senate rule under which the committee had been appointed violated the Constitution's impeachment clause, ${ }^{92}$ which states that the "Senate shall have the sole Power to try all Impeachments."93 To Nixon, the impeachment clause meant that he was entitled to a hearing before the full Senate and not just a

79 Id. at art. II, $₫ 2$.

80 Id. at art. III, $₫ 1$.

81 CHEMERINSKY, supra note 41, p. 3.

82 U.S. Const. art. III, $₫ 2$.

83 Id.

84 Id.

85 CHEMERINSKY, supra note 41, pp. 35-36.

86 Nixon v. United States, 506 U.S. 224, 226 (1993).

87 Id.

88 Id.

89 Id. at 226-228.

$90 I d$. at 228.

$91 \mathrm{Id}$.

92 Id.

93 U.S. Const. art. I, $\$ 3$. 
committee; because he was only given a committee hearing, Nixon claimed that the impeachment proceeding against him was unconstitutional. ${ }^{94}$

The USSC held in a unanimous decision that the impeachment issue before the Court was a nonjusticiable political question..$^{95}$ Justice Rehnquist, writing for the USSC, first reasoned that the Constitution's impeachment clause textually committed impeachment matters to the Senate. ${ }^{96}$ Citing Baker v. Carr, the seminal political question doctrine case, ${ }^{97}$ Justice Rehnquist concluded that the word "try" lacked sufficient precision to afford any "judicially manageable standard of review" and that the word "sole" indicated that authority over impeachment proceedings belonged only to the Senate. ${ }^{98}$ Furthermore, Justice Rehnquist reasoned that history also supported the Court's decision. ${ }^{99}$ According to the Justice, a review of the Constitutional Convention's history and the contemporary commentary supported a reading of the constitutional language that impeachment power rested solely in the Legislature. ${ }^{100}$ Finally, as a prudential matter, Justice Rehnquist reasoned that judicial involvement in the impeachment proceedings would lead to serious political uncertainties. ${ }^{101}$ The "political life of the country" would be exposed to "months, or perhaps years, of chaos" if the judiciary reviewed impeachment proceedings that ultimately lead to the impeachment of the President. ${ }^{102}$ The legitimacy of the judiciary might also come into question, given the uncertainties involved in how to fashion and enforce judicial relief in the impeachment context. ${ }^{103}$

The CCK, by contrast, displayed a different approach to political question cases when it reviewed the National Assembly's impeachment proceedings of South Korean President Roh Moo-hyun. ${ }^{104}$ In The Impeachment of the President (Roh Moo-hyun) Case, the CCK faced the question of whether the National Assembly's impeachment of President Roh was unconstitutional. ${ }^{105}$ The National Assembly voted to impeach the President, 193 out of 271, on the ground that he violated the Public Officials Election Act (POEA), which prohibited incumbent public officials from attempting to influence elections or electoral processes. ${ }^{106}$

94 Nixon, 506 U.S. at 228.

95 Id. at $237-238$.

96 Id. at 229-236.

97 Baker v. Carr, 369 U.S. 186, 217 (1962) (providing the standard for determining whether a case presents nonjusticiable political question).

98 Nixon, 506 U.S. at 230.

99 Id. at 233.

$100 \mathrm{Id}$. at $233-236$.

$101 \mathrm{Id}$. at $236-237$.

102 Id. at 236.

103 Id.

104 Constitutional Court of Korea [CCK] May 14, 2004, 16-1 KCCR 609, 2004Hun-Na1 (S. Kor.).

105 Id.

106 Id. ("The National Assembly of the Republic of Korea proposed the 'motion for the 
According to the National Assembly's impeachment prosecutor, President Roh violated the POEA on numerous occasions when he publicly encouraged the people to vote for candidates from his Uri Party during the 2004 General Election. ${ }^{107}$ After the prosecutor presented the case to the CCK, the CKK ultimately reviewed the case and ruled that there were insufficient constitutional grounds to impeach President Roh. ${ }^{108}$

The CCK first reasoned that the language of the constitution empowered the CCK to review the impeachment proceeding, but only on the grounds proffered by the National Assembly. ${ }^{109}$ After reviewing the POEA, the CCK concluded that President Roh's act of soliciting votes for his Uri Party violated the POEA. ${ }^{110}$ According to the CCK, the history and purpose of the POEA weighed in favor of the CCK's decision. ${ }^{11}$ The POEA was made to prevent public officials from abusing state powers, which was important to the people who had endured decades of hardship living under authoritarian rule before 1987. ${ }^{112}$ Because President Roh's actions constituted a "vestige of [South Korea's] era of government-powerinterfered elections," the CCK concluded that President Roh's actions "denigrated" the POEA's commitment to establishing a free democratic society. ${ }^{113}$

impeachment of the President'

by Assembly members Yoo Yong-tae and Hong Sa-deok and 157 others before the second plenary session at the 246th session on March 12, 2004, and passed the motion by 193 concurrent votes out of the entire Assembly membership of 271."). Article 9 of the Public Officials Election Act provides that "no public official or no one obligated to maintain political neutrality should act in a way unduly influencing the election or otherwise affecting the outcome of the election."

107 Id. (citing the impeachment prosecutor's accusation that the President "violated the Public Officials Election and Election Malpractice Prevention Act" when he stated at several joint press conferences that the public should support his Uri Party).

$108 \mathrm{Id}$. (ruling that impeachment was not warranted because "considering the totality of the specific circumstance where [the President's] statement was made, such statement was made with no affirmative intent to stand against the basic order of free democracy, nor was it an act of grave violation of law fundamentally questioning the principle of the rule of law").

109 Id. ("The Constitutional Court, as a judicial institution, is restrained in principle to the grounds for impeachment stated in the National Assembly's impeachment resolution. Therefore, no other grounds for impeachment except those stated in the impeachment resolution constitute the subject matter to be adjudicated by the Constitutional Court at the impeachment adjudication proceeding.").

$110 \mathrm{Id}$. ("The President... violated the obligation to maintain neutrality concerning elections, by making the statements at the press conferences toward the entire public in support of a particular political party by taking advantage of the political weight and influence of the presidency.").

$111 \mathrm{Id}$. (stating that the protection of the POEA was important because "the constitutional awareness among the public has just begun to sprout in a brief history of democracy" following decades of authoritarian rule).

112 Id.

113 Id. ("The President ... denigrated the current election law as the 'vestige of the era of the government-power-interfered elections."). 
The CCK's interpretation of the impeachment clause, however, ultimately led the CCK to conclude that, based on the principle of proportionality, President Roh's act did not justify removal from office. ${ }^{114}$ After balancing the degree of the "harm to the constitutional order caused by the violation of law" and the "effect to be caused by the removal of the [President] from office," the CCK determined that President Roh's violation of the POEA was not "grave" enough to warrant impeachment. ${ }^{115}$ This was the first time the CCK instituted the "grave violation" standard, which states that a public official can be impeached if (1) "the maintenance of the presidential office can no longer be permitted from the standard of the protection of the Constitution," or (2) "the President has lost the qualifications to administrate state affairs by betraying the trust of the people." 116 On one hand, the CCK acknowledged that President Roh's act threatened the Constitution's commitment to abolish South Korea's authoritative past. ${ }^{117}$ Specifically, the act set a bad example for all public officials and negatively influenced the government's realization of a "rule of law" system. ${ }^{118}$ On the other hand, the CCK recognized that removing the President from office would deprive the "democratic legitimacy" of the popularly-elected President and cause "political chaos arising from the disruption of opinions ... between those who support the President and those who do not." ${ }^{119}$ After balancing all the considerations, the CCK concluded that the grounds to impeach the President were insufficient. ${ }^{120}$ Under the CCK's new "grave violation" standard, the President's act was not grave enough to warrant removal from office. ${ }^{121}$

$114 \mathrm{Id}$. (holding that impeaching the President for his acts "would offend the request that punishment under the Constitution proportionally correspond to the obligation owed by the [President], that is, the principle of proportionality").

$115 \mathrm{Id}$. ("The acts of the President violating the laws were not grave in terms of the protection of the Constitution to the extent that it would require the protection of the Constitution and the restoration of the impaired constitutional order by a decision to remove the President from office.").

116 Id.

117 Id. ("The President's acts denigrating the current law [were] the 'vestige of the era of the government-power-interfered elections"').

118 Id. ("The statements as such made by the President, who should serve as a good example for all public officials, might have significantly negative influence on the realization of a government by the rule of law, by gravely affecting the other public officials obligated to respect and abide by the law.").

119 Id. ("a decision to remove the President from office would deprive the 'democratic legitimacy' delegated to the President by the national constituents through an election during the term of the office and may cause political chaos arising from the disruption of the opinions among the people.").

$120 \mathrm{Id}$. (" $[\mathrm{T}]$ here is no valid ground sufficient to justify a decision to remove the President from office.").

121 Id. 


\subsection{Judicial Responses in the Context of Foreign Policy}

The USSC has also extended the use of the political question doctrine in the context of foreign affairs. ${ }^{122}$ Although the USSC has not been consistent as to which foreign policy issues are justiciable and which present political questions, the USSC has generally held that issues concerning the interpretation and enforcement of treaties pose nonjusticiable political questions. ${ }^{123}$ In Terlinden $v$. Ames, for example, the USSC ruled that the issue of whether a bilateral treaty between the U.S. and Prussia was still enforceable after Prussia was incorporated into Germany presented a nonjusticiable political question. ${ }^{124}$ Justice Fuller, writing for the majority, reasoned that the state's power to carry out treaty obligations "is in its nature political and not judicial, and that the courts ought not to interfere with the conclusions of the political department in that regard." ${ }^{25}$ The USSC further emphasized that U.S. courts "have no right to annul or disregard any [treaty] provisions, unless they violate the Constitution of the United States." ${ }^{126}$ Because the decisions of the Executive regarding the treaty were within its own sphere and in accordance with the Constitution, Justice Fuller ruled that the case before the Court was not open to judicial revision. ${ }^{127}$

The USSC also applied the political question doctrine in Goldwater $v$. Carter, ${ }^{128}$ which involved the question of whether the Executive could terminate a treaty with Taiwan without the consent of the U.S. Senate. ${ }^{129}$ Justice Rehnquist, writing for the plurality, ruled that the issue was a "nonjusticiable political dispute that should be left for resolution by the Executive and Legislative Branches." ${ }^{130}$ Because the constitution was silent as to the standard of review for the termination of treaties and because there was no uniform standard by which the termination procedures of a treaty could be reviewed, Justice Rehnquist concluded that the instant case "must surely be controlled by political standards" and, therefore, was nonjusticiable. ${ }^{131}$

122 Oetjen v. Central Leather Co., 246 U.S. 297, 302 (1918) ("The conduct of the foreign relations of our Government is committed by the Constitution to the Executive and Legislative 'the political' Departments of the Government, and the propriety of what may be done in the exercise of this political power is not subject to judicial inquiry or decision."). See also Chicago \& S. Air Lines v. Waterman S.S. Corp., 333 U.S. 103, 111 (1948).

123 See, e.g., Terlinden v. Ames, 184 U.S. 270, 290 (1902). See also CHEMERINSKY, supra note 41, p. 148.

124 Terlinden, 184 U.S. at 290.

$125 \mathrm{Id}$. at 288.

126 Id. at $288-289$.

127 Id. at 290.

128 Goldwater v. Carter, 444 U.S. 996 (1979).

$129 \mathrm{Id}$. at 1002.

$130 \mathrm{Id}$. at 1003.

131 Id. 
The CCK, by contrast, has adopted a more open stance towards reviewing issues involving the interpretation and enforcement of treaties. ${ }^{132}$ South Korea's seminal political question doctrine case in the area of foreign policy, the Comfort Women Victims Case, involved the issue of whether the South Korean Executive's act of omission in a bilateral Agreement with Japan was unconstitutional. ${ }^{133}$ The Agreement was signed on June 22, 1965, approximately twenty years after the Korean peninsula was liberated from Japanese colonial rule. ${ }^{134}$ During Korea's thirty-five years as a colonial subject of Japan, hundreds of Korean women, known as "comfort women," were forced into sexual slavery by the Japanese Imperial Army. ${ }^{135}$ After liberation, South Korea and Japan entered into diplomatic talks and signed the 1965 Agreement, under which Japan agreed to provide South Korea with up to $¥ 108,000,000,000$ (\$800 million) in economic aid. ${ }^{136}$ The comfort women issue was neither discussed at the talks leading up to the signing of the Agreement nor included in any of the provisions. ${ }^{137}$ The heart of the dispute in the Comfort Women Victims Case concerned whether the 1965 Agreement covered the damages claims of the comfort women. ${ }^{138}$

Article II of the Agreement stated, "The Contracting Parties confirm that the problem concerning property, rights and interests of the two Contracting Parties and their nationals and concerning claims between the Contracting Parties and their nationals . . . is settled completely and finally" ${ }^{139}$ To the Japanese government, Article II meant that the damages claims of all Koreans, including comfort women, were comprehensively included in the Agreement and, therefore, all future damages claims by Koreans were terminated. ${ }^{140}$ By contrast, the South Korean government interpreted Article II to not include the comfort women's damages claims, as they concerned Japan's "unlawful acts against humanity." 141

132 See Constitutional Court of Korea [CCK] Aug. 30, 2011, 23-2(A) KCCR 366, 2006HunMa788 (S. Kor.).

133 Id.

134 Treaty on Basic Relations Between Japan and Republic of Korea, Japan-S. Kor., June 22, 1965, No. 8471, 44 U.N.T.S. 1966.

135 Constitutional Court of Korea [CCK] Aug. 30, 2011, 23-2(A) KCCR 366, 2006Hun-Ma788 (S. Kor.) ('The complainants are 'victims known as comfort women' who were forced into sexual slavery by the Japanese military.").

136 Id.

137 Id.

$138 \mathrm{Id}$. " The complainants have stated that, as to whether the damage claims they hold against Japan as comfort women have been extinguished by Article 2 Section 1 of the Agreement, Japan refuses to provide them with compensation on grounds that the claims have expired by the aforementioned provision, while the Korean government does not believe that the claims issue has been settled by the Agreement").

139 Treaty on Basic Relations Between Japan and Republic of Korea, art II, June 22, 1965, 44 U.N.T.S. 1966.

140 Constitutional Court of Korea [CCK] Aug. 30, 2011, 23-2(A) KCCR 366, 2006Hun-Ma788 (S. Kor.) ("Japan refuses to provide [the comfort women] with compensation on grounds that the claims have expired by the aforementioned provision.").

141 Id. ("the Korean government does not believe that the [comfort women's] claims issue has 
Despite their disagreements, the executives of South Korea and Japan did not attempt to settle their dispute under Article III of the Agreement, which mandated that "[a]ny dispute between the Contracting Parties concerning the interpretation and implementation of the present Agreement shall be settled, first of all, through diplomatic channels." ${ }^{142}$ Because the comfort women believed that the South Korean government failed to engage Japan to resolve the "dispute" over their damages claims, the comfort women claimed that the Executive's act of omission was unconstitutional. ${ }^{143}$

The CCK ultimately ruled that the Executive's failure to act upon the comfort women's damages claims was unconstitutional. ${ }^{144}$ Although the CCK acknowledged that the interpretation and enforcement of treaties concerned "highly political actions," the CCK found enough of a constitutional basis in the case to warrant judicial review. ${ }^{145}$ The CCK first determined that a real "dispute" existed between South Korea and Japan under the terms of the Agreement. ${ }^{146}$ Given that South Korea and Japan disagreed over whether the comfort women's damages claims were included in Article II, the CCK reasoned that there was a real "dispute between the Contracting Parties" over the meaning of Article II that had to be "settled" pursuant to Article III. ${ }^{147}$ The CCK then ruled that, despite the deference traditionally afforded to the Executive in matters concerning foreign policy and executive discretion, the comfort women's constitutionally guaranteed rights to "human dignity" under Article 10 of the Constitution obliged the Executive to negotiate with Japan to resolve their damages claims. ${ }^{148}$ Article 10 states, "All citizens shall be assured of human worth and dignity and have the right to pursuit of happiness. It shall be the duty of the State to confirm and guarantee the fundamental and inviolable human rights of individuals." ${ }^{149}$ Because the Executive's

been settled by the Agreement.").

142 Treaty on Basic Relations Between Japan and Republic of Korea, art III, June 22, 1965, 44 U.N.T.S. 1966.

143 Constitutional Court of Korea [CCK] Aug. 30, 2011, 23-2(A) KCCR 366, 2006Hun-Ma788 (S. Kor.) (" $\mathrm{T}]$ he complainants filed this constitutional complaint challenging the constitutionality of the respondent's omission to act, arguing that the respondent is not fulfilling its duty to take action to resolve the interpretation dispute as stipulated by Article 3 of the Agreement.").

144 Id. ("The respondent's failure to take action in this case violates the significant fundamental rights of the complainants enshrined in the Constitution.").

145 Id.

146 Id. (ruling that the "disparate views [of Japan and South Korea] qualify as a 'dispute' provided in Article 3 of the Agreement").

147 Id.

148 Id. ("rights guaranteed under the Constitution are binding on all state powers, so administrative authority should also be exercised in a way that fundamental rights are guaranteed effectively in accordance with the duty to protect fundamental rights").

149 Constitution of the Republic of Korea Oct. 29, 1987, chap. II, art. 10 (S. Kor.) (emphasis added). 
act of omission failed to protect the constitutional rights of the comfort women, the CCK ruled that the Executive violated the Constitution. ${ }^{150}$

\section{The Reasons Why the U.S. and South Korea Differ in Approach to Poli- tical Questions}

The United States Supreme Court (USSC) and Constitutional Court of Korea (CCK) have adopted sharply different positions regarding the justiciability of political questions. In the context of impeachment, the USSC decided not to review the Senate's impeachment proceedings in Nixon $v$. United States, ${ }^{151}$ while the CCK in The Impeachment of the President (Roh Moo-hyun) Case reviewed and entered judgment on the National Assembly's impeachment of South Korea's President. ${ }^{152}$ The CCK also demonstrated its openness to reviewing political questions in The Comfort Women Victims Case when it reviewed the constitutionality of the Executive's act of omission in an international treaty. ${ }^{153}$ By contrast, the USSC in Terlinden v. Ames ${ }^{154}$ and Goldwater v. Carter ${ }^{155}$ refrained from reviewing issues concerning the interpretation and enforcement of treaties. A comparison of the experiences of the USSC and CCK reveals several reasons why they apply different approaches towards the justiciability of political questions. Specifically, (1) the text of their constitutions, (2) their views about the proper role of the judiciary, and (3) prudential factors help explain why they differ in approach.

\subsection{Constitutional Text}

One reason for the U.S. and South Korea's difference in approach concerns the text of their constitutions. On one hand, the USSC's decision to not review the impeachment proceedings in Nixon $v$. United States was largely due to the language of the Constitution's impeachment clause, ${ }^{156}$ which states that the "Senate shall have the sole Power to try all Impeachments." ${ }^{157}$ Justice Rehnquist emphasized that the word "sole" indicated that only the Senate possessed authority over impeachment proceedings in the U.S. system. ${ }^{158}$ The USSC also cited the text of the Constitution when it refrained from reviewing the Executive's

150 Constitutional Court of Korea [CCK] Aug. 30, 2011, 23-2(A) KCCR 366, 2006Hun-Ma788 (S. Kor.). ("[The Executive's] blocking the repayment of damage claims is ... directly associated with the infringement of fundamental dignity and value of human beings.").

151 Nixon v. United States, 506 U.S. 224, 226 (1993).

152 Constitutional Court of Korea [CCK] May 14, 2004, 16-1 KCCR 609, 2004Hun-Na1 (S. Kor.).

153 Constitutional Court of Korea [CCK] Aug. 30, 2011, 23-2(A) KCCR 366, 2006Hun-Ma788 (S. Kor.).

154 Terlinden v. Ames 184 U.S. 270 (1902).

155 Goldwater v. Carter, 444 U.S. 996 (1979).

156 Nixon, 506 U.S. at 229-36.

157 U.S. Const. art. I, $\$ 3$.

158 Nixon, 506 U.S. at 230. 
enforcement of treaties in Terlinden v. Ames ${ }^{159}$ and Goldwater v. Carter. ${ }^{160}$ The plain language of Article II of the Constitution demonstrated that the authority to oversee treaties was primarily reserved to the President with the advice and consent of the Senate. ${ }^{161}$

By contrast, the CCK's review of the impeachment proceedings of President Roh Moo-hyun in The Impeachment of the President (Roh Moo-hyun) Case was explicitly permitted by the text of South Korea's Constitution. ${ }^{162}$ Because one of the CCK's five areas of jurisdiction is "impeachment proceedings brought against high-ranking public officials," 163 the CCK's review of the National Assembly's impeachment proceedings did not infringe upon the legislature's traditional area of control. ${ }^{164}$ Furthermore, in the area of foreign policy, the text of Article 10 of the Constitution persuaded the CCK in The Comfort Women Victims Case to review whether the Executive's act of omission in the 1965 Agreement violated the Executive's duty to "confirm and guarantee the fundamental and inviolable human rights of individuals." 165 Although Article 73 of the Constitution explicitly empowered the Executive to "conclude and ratify treaties," the CCK placed more weight on its powers to review Executive actions based on the text of Article $10 .{ }^{166}$

\subsection{Views Concerning the Proper Role of the Judiciary}

Another reason for the difference in approach between the U.S. and South Korea towards political questions concerns their views about the appropriate role of the judiciary. When there is no manageable legal standard to apply in a case involving a political question, the USSC has tended to exercise restraint in order to not overstep its role by inappropriately engaging in "lawmaking." ${ }^{67}$ In Nixon v. United States, for example, the USSC decided not to review the impeachment proceedings in part because the there was no "judicially manageable standard of review" to determine whether the subcommittee's hearing with

159 Terlinden v. Ames 184 U.S. 270, 290 (1902).

160 Goldwater v. Carter, 444 U.S. 996, 1002-03 (1979).

161 See U.S. Const. art. II, $\$ 2$.

162 Constitutional Court of Korea [CCK] May 14, 2004, 16-1 KCCR 609, 2004Hun-Na1 (S. Kor.).

163 Constitutional Court of Korea, Jurisdiction: Adjudication on Impeachment. [online]. Available at: <http://english.ccourt.go.kr/cckhome/eng/jurisdiction/jurisdiction/adjuOnConsOfStatutes.do> Accessed: 08.12.2018.

164 Constitutional Court of Korea [CCK] May 14, 2004, 16-1 KCCR 609, 2004Hun-Na1 (S. Kor.).

165 Constitutional Court of Korea [CCK] Aug. 30, 2011, 23-2(A) KCCR 366, 2006Hun-Ma788 (S. Kor.) (reviewing Article 10 of the 1987 South Korean Constitution). 166 Id.

167 Mulhern, supra note 3, pp. 164-174 (defending the political question doctrine to help protect the legislature's sphere of authority). 
Nixon met the terms of the impeachment clause. ${ }^{168}$ Had the USSC made a ruling on the impeachment proceedings, the USSC, according to Justice Rehnquist, would have inappropriately created new laws in an area reserved to the legislature. ${ }^{169}$ Furthermore, the USSC in Goldwater v. Carter similarly ruled that the treaty-termination issue was nonjusticiable in part because there was no clear standard by which the termination procedures of a treaty could be reviewed. ${ }^{170}$ In order to avoid intervening in a field where the Executive has more training and expertise, the USSC decided to exercise restraint and rule that the issue was nonjusticiable. ${ }^{171}$

The CCK, by contrast, has shown to be active even when there is no clear legal standard to apply in a case involving a political question. ${ }^{172}$ In The Impeachment of the President (Roh Moo-hyun) Case, the CCK reviewed for the first time an impeachment challenge brought against President Roh and ruled that, based on the principle of proportionality, the President's act was not "grave" enough to warrant removal from office. ${ }^{173}$ Although the CCK had applied the proportionality test before in other contexts, the CCK instituted for the first time the "grave violation" standard for purposes of impeachment. ${ }^{174}$ Notwithstanding criticisms that the CCK engaged in lawmaking, the CCK set forth a "grave violation" test by which a public official could be impeached if (1) "the maintenance of the presidential office can no longer be permitted from the standard of the protection of the Constitution," or (2) "the President has lost the qualifications to administrate state affairs by betraying the trust of the people." 175 Furthermore, in The Comfort Women Victims Case, the CCK actively reviewed the Executive's actions pursuant to the 1965 Agreement, even though the CCK had no preexisting standard by which to review the political issue. ${ }^{176}$ Although the CCK acknowledged that deference should be afforded to the Executive in matters concerning foreign affairs, the CCK nevertheless constructed a standard of review from the terms of

168 Nixon v. United States, 506 U.S. 224, 230 (1993).

169 Id. at 233-236.

170 Goldwater v. Carter, 444 U.S. 996, 1003 (1979).

171 Id.

172 See PARK, supra note 5, pp. 66-67.

173 Constitutional Court of Korea [CCK] May 14, 2004, 16-1 KCCR 609, 2004Hun-Na1 (S. Kor.) (holding that impeaching the President for his acts "would offend the request that punishment under the Constitution proportionally correspond to the obligation owed by the [President], that is, the principle of proportionality").

174 Id. ("The acts of the President violating the laws were not grave in terms of the protection of the Constitution to the extent that it would require the protection of the Constitution and the restoration of the impaired constitutional order by a decision to remove the President from office.").

175 Id.

176 Constitutional Court of Korea [CCK] Aug. 30, 2011, 23-2(A) KCCR 366, 2006Hun-Ma788 (S. Kor.). 
the actual 1965 Agreement and concluded that the Executive's failure to engage Japan about the comfort women's damages claims was unconstitutional. ${ }^{177}$

\subsection{Prudential Factors}

Prudential factors further explain why the USSC and CCK have adopted different positions regarding the justiciability of political questions. In Nixon $v$. United States, the USSC ruled that the issue of impeachment was nonjusticiable in part because, as a prudential matter, judicial intervention would lead to serious political uncertainties. ${ }^{178}$ Judicial intervention, according to Justice Rehnquist, would create chaos and undermine the democratic legitimacy of the legislators who were elected by the American electorate. ${ }^{179}$ Concerns about preserving judicial legitimacy also restrained the USSC from reviewing the impeachment proceedings in Nixon, given that any judgment entered by the USSC likely would have been ignored by the other branches. ${ }^{180}$ Uncertainties over the USSC's capacity to fashion and enforce judicial relief in the impeachment context also influenced the USSC's conclusion that the issue was nonjusticiable. ${ }^{181}$ Furthermore, in Terlinden $v$. Ames, the USSC ruled, as a prudential matter, that the issue concerning the U.S.-Prussia treaty was nonjusticiable, in part to preserve mutual respect and separation of powers between the political branches. ${ }^{182}$ Because the issue of foreign affairs fell within the Executive's traditional sphere of authority, the USSC determined that the "courts ought not to interfere" with the Executive's handling of the treaty. ${ }^{183}$

In South Korea, by contrast, prudential factors have weighed in favor of the CCK taking a more active role in reviewing political questions. ${ }^{184}$ In The Impeachment of the President (Roh Moo-hyun) Case, the National Assembly presented its impeachment proceedings to the CCK for a final decision. ${ }^{185}$ Although the impeachment proceedings originated in the National Assembly, a ruling by the CCK posed less of a threat to the principle of separation of powers in the South Korean context. ${ }^{186}$ Unlike USSC Justices, who are all appointed by the U.S. President with the advice and consent of the Senate, in South Korea three of the nine Justices are elected by the National Assembly, three are designated by the Chief Justice of the Supreme Court, and the remaining three are appointed

177 Id. (constructing a standard of review based on the text of Article II and Article III of the 1965 Agreement and on Article 10 of the Constitution).

178 Nixon v. United States, 506 U.S. 224, 236-37 (1993).

$179 \mathrm{Id}$. at 236.

$180 \mathrm{Id}$.

$181 \mathrm{Id}$.

182 Terlinden v. Ames, 184 U.S. 270, 288 (1902).

183 Id. at 290.

184 See PARK, supra note 5, pp. 104-105.

185 Constitutional Court of Korea [CCK] May 14, 2004, 16-1 KCCR 609, 2004Hun-Na1 (S. Kor.).

186 See HAHM, supra note 5, pp. 16-17. 
by the President. ${ }^{187}$ As such, any decision by the CCK already represents a kind of separation of powers between the political branches. ${ }^{188}$ Furthermore, given South Korea's more recent history of authoritarian rule and the manner by which the CCK was established with broad public and bipartisan support, the CCK derives much of its legitimacy from actively keeping other political branches accountable and protecting the constitutional rights of the people, ${ }^{189}$ as shown in The Comfort Women Victims Case. ${ }^{190}$ Although the issue in that case centered on foreign policy, a matter traditionally reserved to the authority of the Executive, the issue's relevance to the comfort women's constitutional right to human dignity justified the CCK's adjudication of the case. ${ }^{191}$ Although three of the Justices in that case expressed in dissent that the CCK should have deferred to the Executive's discretion, the remaining six Justices emphasized that judicial review was warranted because the Executive failed to "take concrete action ... to protect [the people's] fundamental rights." 192

Taken together, the text of the U.S. and South Korean constitutions, their views about the proper role of the judiciary, and prudential factors help explain why the USSC and the CCK have taken different approaches towards adjudicating political questions. Although there is still debate as to whether courts should take a more active or more restrained role in reviewing political questions, ${ }^{193}$ the experiences of the U.S. and South Korea provide valuable lessons for each other to consider.

\section{Conclusion: Lessons from the Experiences of the U.S. and South Korea}

The United States Supreme Court (USSC) and the Constitutional Court of Korea (CCK) have adopted sharply different positions regarding the justicia-

187 Constitution of the Republic of Korea Oct. 29, 1987, chap. VI, art. 111 (S. Kor.). Constitutional Court of Korea, Organization: Justice. [online]. Available at: <http://english.ccourt.go.kr/ cckhome/eng/introduction/organization/organization.do\#none> Accessed: 08.12.2018.

188 See id. (suggesting that the distribution of Justice appointments indicates that the three branches are equally represented in the CCK).

189 HAHM, supra note 5, p. 23 n.118 (reviewing how the CCK enjoys broad support from the public when adjudicating cases).

190 Constitutional Court of Korea [CCK] Aug. 30, 2011, 23-2(A) KCCR 366, 2006Hun-Ma788 (S. Kor.).

191 Id. ("[The Executive's] blocking the repayment of damage claims is ... directly associated with the infringement of fundamental dignity and value of human beings.").

192 Id.

193 Compare COHEN, supra note 12, pp. 5-6 (arguing that too much judicial restraint to hearing political questions is bad and that what is needed is a politics-reinforcing political question doctrine that can balance the need for robust review with the desire for robust debate.), and SKINNER, supra note 12, p. 431 (encouraging federal courts to not simply dismiss political question cases as nonjusticiable but to adjudicate more on the merits whether a branch acted constitutionally), with BARKOW, supra note 12, pp. 239-241 (contending that courts should be deferential to other branch's spheres of authority by adhering to the classical political question doctrine). 
bility of "political questions." On one hand, the USSC has generally refrained from hearing cases concerning inherently political matters, as shown in Nixon v. United States, ${ }^{194}$ Terlinden v. Ames, ${ }^{195}$ and Goldwater v. Carter.${ }^{196}$ On the other hand, the CCK has regularly tried cases concerning political questions, as demonstrated in The Impeachment of the President (Roh Moo-hyun) Case ${ }^{197}$ and The Comfort Women Victims Case. ${ }^{198}$ The text of the U.S. and South Korean constitutions, their views about the proper role of the judiciary, and prudential factors primarily explain why the USSC and the CCK have taken different approaches towards adjudicating political questions. ${ }^{199}$

Although the approaches of the U.S. and South Korea each developed within the specific context of each nation, there are several lessons each country can learn by considering the experiences of the other. On one hand, the CCK might learn from the example of the USSC that there are benefits to taking on a more restrained approach towards reviewing political questions. Engaging in quasilawmaking functions like the CCK did when it created the "grave violation" standard in The Impeachment of the President (Roh Moo-hyun) Case risks violating the constitutional commitment to separation of powers. ${ }^{200}$ Although the CCK was established with a mandate to check the other political branches from acquiring tyrannical rule, that mandate did not grant the CCK a license to act as a tyrant. ${ }^{201}$

Furthermore, the CCK might learn from the USSC's example in Goldwater $v$. Carter that adjudicating political-question cases when there is no manageable legal standard poses serious risks of judicial unpredictability and inconsistency. ${ }^{202}$ In The Comfort Women Victims Case, for example, even though there was no clearly established standard by which to review the procedures of a treaty, the

194 Nixon v. United States, 506 U.S. 224, 226 (1993).

195 Terlinden v. Ames, 184 U.S. 270, 288 (1902).

196 Goldwater v. Carter, 444 U.S. 996, 1003 (1979).

197 Constitutional Court of Korea [CCK] May 14, 2004, 16-1 KCCR 609, 2004Hun-Na1 (S. Kor.).

198 Constitutional Court of Korea [CCK] Aug. 30, 2011, 23-2(A) KCCR 366, 2006Hun-Ma788 (S. Kor.).

199 See supra part IV.

200 Several Korean and American scholars have argued for judicial restraint in the political question context in order to protect the role of the legislature. See, e.g., LIM, Jibong. Korean Constitutional Court Standing at the Crossroads: Focusing on Real Cases and Variational Types of Decisions. Loyola of Los Angeles International and Comparative Law Review, 2002 , vol. 24, p. 328 (reviewing various arguments by Korean scholars who call for judicial restraint from political questions involving legislative functions); MULHERN, supra note 3, pp. 164-174 (defending the political question doctrine on grounds of separation of powers).

201 See HAHM, supra note 5, p. 14 (reviewing arguments that the CCK cannot usurp the powers of the people nor claim judicial supremacy).

202 Goldwater v. Carter, 444 U.S. 996, 1004 (1979) (claiming that there were no standards in the Constitution governing rescission of treaties). 
CCK Justices nevertheless took it upon themselves to construct a standard from the terms of the 1965 Agreement; ${ }^{203}$ whether their construction was reasonable and fair or one that was made based on the predilections of the Justices is still a matter of debate. ${ }^{204}$ In this regard, the example of the USSC might instruct the CCK about the advantages of adhering to a common legal "starting point" so that the people and political branches can organize themselves around shared and certain legal standards. ${ }^{205}$

Furthermore, the example of the USSC in Nixon v. United States and Goldwater v. Carter might instruct the CCK about the benefits of deferring to the other political branches, especially in matters concerning their areas of expertise. ${ }^{206}$ Although a primary function of the CCK is to say what the law is even in cases involving political questions, it may be more prudent for Justices to be humble and accepting of their limitations. ${ }^{207}$ Because the CCK is less trained and experienced than the other branches in matters concerning impeachment and international treaties, the CCK risks making bad law and hurting its reputation whenever it reviews politically sensitive questions. ${ }^{208}$

On the other hand, the USSC might learn from the CCK about the benefits of playing a more active role in adjudicating political questions. Although the USSC's responsibility is not to "make" the law, a lack of manageable legal standards should not always stop the USSC from reviewing new political-question cases. ${ }^{209}$ Like the CCK in The Impeachment of the President (Roh Moo-hyun) Case ${ }^{210}$ and The Comfort Women Victims Case, ${ }^{211}$ the USSC might consider establishing new legal standards to expand the scope of constitutional protections to cover

203 Constitutional Court of Korea [CCK] Aug. 30, 2011, 23-2(A) KCCR 366, 2006Hun-Ma788 (S. Kor.) (constructing a standard of review based on the text of Article II and Article III of the 1965 Agreement and on Article 10 of the Constitution).

204 Three of the CCK Justices argued in dissent that the majority's construction of the Agreement was wrong. See id.

205 Goldwater v. Carter, 444 U.S. 996, 1003 (1979) (claiming that the presence of multiple standards makes review of political questions nonjusticiable).

206 See Nixon v. United States, 506 U.S. 224, 233-36 (1993) (acknowledging expertise of legislature in matters of impeachment); Goldwater, 444 U.S. at 1003 (1979) (exercising judicial restraint by deferring to Executive who had more training and expertise in matters concerning treaties).

207 SCHARPF, supra note 31, p. 567 (claiming that courts should humbly defer the resolution of some political questions to the other branches where those branches have greater information and expertise).

208 Id.

209 See HENKIN, supra note 28, p. 599 (claiming that despite a lack of manageable legal standards, political questions might still pose interpretive questions that courts commonly resolve); CHEMERINSKY, supra note 19, p. 139.

210 Constitutional Court of Korea [CCK] May 14, 2004, 16-1 KCCR 609, 2004Hun-Na1 (S. Kor.).

211 Constitutional Court of Korea [CCK] Aug. 30, 2011, 23-2(A) KCCR 366, 2006Hun-Ma788 (S. Kor.). 
factually-novel political issues. The use of a proportionality test, like the one used by the CCK in The Impeachment of the President (Roh Moo-hyun) Case, might particularly be helpful in this regard. ${ }^{212}$ The example of the CCK in The Comfort Women Victims Case also demonstrates how a constitutional court can construct a new legal standard in a manner that is innovative while consistent with the constitution. ${ }^{213}$

The example of the CCK might also inform the USSC about the prudential advantages of reviewing political questions. Given that government power is divided through a system of checks and balances, the USSC might learn from the experience of the CCK that reviewing political questions is a form of judicial power to prevent other branches from acquiring tyrannical rule. ${ }^{214} \mathrm{By}$ keeping the other branches accountable to their obligations under the Constitution, the USSC might actually enhance its legitimacy and prestige. ${ }^{215}$ Although concerns about tyrannical rule might be more pressing in South Korea given its more recent history of authoritarian rule, the need to prevent the "tyranny of the majority" in the U.S. has always been a central concern. ${ }^{216}$

Furthermore, the USSC might learn from the CCK that adjudicating political questions might enhance the judiciary's support from the public. In The Comfort Women Victims Case, for example, the CCK showed that by committing itself to protecting the people's rights to human dignity, the CCK enhanced the CCK's reputation and standing among the people. ${ }^{217}$ Perhaps the USSC might consider taking a more active approach towards protecting individual rights, such as dignity, even if doing so involves adjudicating politically sensitive questions. ${ }^{218}$ Although reviewing political questions for the sake of the people might undermine the USSC's relationship with the other branches, the example of the CCK

212 Constitutional Court of Korea [CCK] May 14, 2004, 16-1 KCCR 609, 2004Hun-Na1 (S. Kor.) (ruling that impeachment was not warranted after applying a proportionality test).

213 Constitutional Court of Korea [CCK] Aug. 30, 2011, 23-2(A) KCCR 366, 2006Hun-Ma788 (S. Kor.) (constructing a standard of review based on the text of Article II and Article III of the 1965 Agreement and on Article 10 of the Constitution).

214 See REDISH, supra note 41, pp. 1045-1046 (claiming that judicial review of political questions is needed to restrain other branches from unconstitutional majoritarian control); CHEMERINSKY, supra note 41, pp. 99-105.

215 See CHEMERINSKY, supra note 41, pp. 133-138.

216 CHEMERINSKY, supra note 19, p. 8 ("[T] he Constitution needs to be understood as an intentionally anti-majoritarian document”).

217 Constitutional Court of Korea [CCK] Aug. 30, 2011, 23-2(A) KCCR 366, 2006Hun-Ma788 (S. Kor.).

218 There is no right to dignity explicitly written in the U.S. Constitution. See DORSEN et al., supra note 14, p. 754 (stating that the "U.S. Constitution does not include an explicit right to dignity, but the USSC has found this protection in the Eighth and Fourteenth Amendments"); FREEMAN, Michelle. The Right to Dignity in the United States. Hastings Law Journal, 2017, vol. 68, p. 1137 (claiming that the USSC has consistently failed to define 'dignity' as a legal concept). 
demonstrates that the legislative and executive branches will more likely acquiesce to judicial decisions that enjoy broad support from the public..$^{219}$

Taken together, the experiences of the USSC and CCK demonstrate that adjudicating political questions involvest both advantages and disadvantages. On one hand, the CCK has shown how a more active approach towards reviewing political questions can (1) create legal standards that keep government branches accountable in novel situations, (2) prevent a political branch from acquiring tyrannical rule, and (3) enhance the judiciary's legitimacy and standing in the public. On the other hand, the USSC has demonstrated how a more restrained approach towards reviewing political questions may (1) strengthen the commitment of all branches to the principle of separation of powers (2) enhance the consistency and predictability of judicial decisions, and (3) lead to the resolution of an issue by the political branch with the most training and expertise. Although the specific context of each nation will determine which approach is more appropriate, the experiences of the U.S. and South Korea provide valuable lessons that they can learn from each other.

\section{References}

BARKOW, Rachel, E. More Supreme than Court? The Fall of the Political Question Doctrine and the Rise of Judicial Supremacy. Columbia Law Review, 2002, vol. 102, pp. 239-241.

BICKEL, Alexander, The Least Dangerous Branch. New Haven: Yale University Press, 1962, p. 184.

CHEMERINSKY, Erwin, Constitutional Law: Principles and Policies. Fifth Edition. New York: Wolters Kluwer Law \& Business, 2015, p. 135.

CHEMERINSKY, Erwin, Interpreting the Constitution. New York: Praeger Publishers, 1987, pp. 99-105.

COHEN, Harlan, Grant. A Politics-Reinforcing Political Question Doctrine. Arizona State Law Journal, 2017, vol. 49, pp. 5-6.

Court of Korea, Organization: Justices. [online]. Available at: <http://english.ccourt. go.kr/cckhome/eng/introduction/organization/organization.do\#none> Accessed: 08.12.2018. Constitutional Court of Korea [CCK] Aug. 30, 2011, 23-2(A) KCCR 366, 2006Hun-Ma788 (S. Kor.).

Constitutional Court of Korea, About the Court. [online]. Available at: <http://english.ccourt.go.kr/cckhome/eng/introduction/aboutTheCourt/aboutTheCourt.do> Accessed: 08.12.2018.

Constitutional Court of Korea, History of Constitutional Adjudication. [online]. Available at: <http://english.ccourt.go.kr/cckhome/eng/introduction/history/historyOfConsAdju.do> Accessed: 08.12.2018.

Constitutional Court of Korea, Jurisdiction: Adjudication on Competence Dispute. [online]. Available at: <http://english.ccourt.go.kr/cckhome/eng/jurisdiction/jurisdiction/ adjuOnConsOfStatutes.do> Accessed: 08.12.2018.

219 See HAHM, supra note 5, p. 23 n.118 (stating that the CCK's broad public support has provided it legitimacy with respect to the other branches). 
Constitutional Court of Korea, Jurisdiction: Adjudication on Dissolution of a Political Party. [online]. Available at: <http://english.ccourt.go.kr/cckhome/eng/jurisdiction/jurisdiction/adjuOnConsOfStatutes.do $>$ Accessed: 08.12.2018.

Constitutional Court of Korea, Jurisdiction: Adjudication on Impeachment. [online]. Available at: <http://english.ccourt.go.kr/cckhome/eng/jurisdiction/jurisdiction/adjuOnConsOfStatutes.do> Accessed: 08.12.2018.

Constitutional Court of Korea, Jurisdiction: Adjudication on the Constitutionality of Statutes. [online]. Available at: <http://english.ccourt.go.kr/cckhome/eng/jurisdiction/ jurisdiction/adjuOnConsOfStatutes.do> Accessed: 08.12.2018.

Constitutional Court of Korea, Jurisdiction: Constitutional Complaint. [online]. Available at: <http://english.ccourt.go.kr/cckhome/eng/jurisdiction/jurisdiction/adjuOnConsOfStatutes.do $>$ Accessed: 08.12.2018.

DANSBY, Joshua W. Rule of Law in the United States. Stability is One of the World's Most Valued Commodities. International and Comparative Law Review, 2017, vol. 17, p. 147.

DORSEN, Norman et al., Comparative Constitutionalism: Cases and Materials. Third Edition. St. Paul: West Academic Publishing, 2016, pp. 38-39.

FIELD, Oliver, P. The Doctrine of Political Questions in the Federal Courts. Minnesota Law Review, 1924, vol. 8, p. 512.

FREEMAN, Michelle. The Right to Dignity in the United States. Hastings Law Journal, 2017, vol. 68, p. 1137.

HAHM, Chaihark. Beyond "Law v. Politics" in Constitutional Adjudication: Lessons from South Korea. International Journal of Constitutional Law, 2012, vol. 10, p. 1.

HAHM, Chaihark. To Make "We the People": Constitutional Founding in Postwar Japan and South Korea. International Journal of Constitutional Law, 2010, vol. 8, p. 3.

HENKIN, Louis. Is There a "Political Question" Doctrine?. Yale Law Journal, 1976, vol. 85, p. 599.

LAU, Holning. Introduction to the Symposium Issue: Pluralism in Asia. North Carolina Journal of International Law \& Commercial Regulation, 2011. vol 36, p. 499.

LAU, Holning. The Language of Westernization in Legal Commentary. American Journal of Comparative Law, 2013, vol. 61, p. 508.

LIM, Jibong. A Comparative Study of the Constitutional Adjudication Systems of the U.S., Germany and Korea. Tulsa Journal of Comparative \& International Law, 1999, vol. 6, pp. 142-144.

LIM, Jibong. Korean Constitutional Court Standing at the Crossroads: Focusing on Real Cases and Variational Types of Decisions. Loyola of Los Angeles International and Comparative Law Review, 2002, vol. 24, p. 328.

MULHERN, Peter, J. In Defense of the Political Question Doctrine, University of Pennsylvania Law Review, 1988, vol. 137, p. 97.

PARK, Jonghyun. The Judicialization of Politics in Korea. Asian-Pacific Law \& Policy Journal, 2008, vol. 10, pp. 66-67.

REDISH, Martin. Judicial Review and the Political Question. Northwestern University Law Review, 1985, vol. 79, pp. 1045-1046.

SCHARPF, Fritz. Judicial Review and the Political Question Doctrine: A Functional Analysis. Yale Law Journal, 1966, vol. 75, pp. 539-540.

SCHAUER, Frederick. Easy Cases. Southern California Law Review, 1985, vol. 58, p. 404.

SIMONIS, Mindaugas. The Role of Judicial Ethics in Court Administration: From Setting the Objectives to Practical Implementation. Baltic Journal of Law \& Politics, 2017, vol. 10, pp. 92-93. 
ICLR, 2019, Vol. 19, No. 1.

SKINNER, Gwynne. Misunderstood, Misconstrued, and Now Clearly Dead: The "Political Question Doctrine" as a Justiciability Doctrine. Journal of Law and Politics, 2014, vol. 29, p. 431.

The Constitutional Court of Korea: The First Ten Years of the Korean Constitutional Court. Sixteenth Volume. Seoul, 2001.

TOMOSZEK, Maxim. Impeachment in the U.S. Constitution and Practice - Implications for the Czech Constitution, International and Comparative Law Review, 2017, vol. 17, pp. 133-136. 